Study the Morphological and Mechanical Properties of Ultra-high Molecular weight polyethylene UHMWPE: Polytetrafluroethylene PTFE binary blends
Alyaa H .Abdalsalam
OlfatA.Mahmood
Gaid K.Salman

\title{
Study the Morphological and Mechanical Properties of Ultra-high Molecular weight polyethylene UHMWPE: Polytetrafluroethylene PTFE binary blends
}

\author{
Alyaa H .Abdalsalam ${ }^{1}$, OlfatA.Mahmood ${ }^{2}$ and Gaid K.Salman ${ }^{3}$ \\ ${ }^{1}$ Nano Technology and advanced material Research center-Technology University \\ ${ }^{2}$ Science College- Diyala University \\ ${ }^{3}$ Nano Technology and advanced material Research center-Technology University
}

Received 16 December 2015

Accepted 28 February 2016

\section{$\underline{\text { Abstract }}$}

In this research, it has been investigated the effect of addition High performance polymer Polytetrafluroethylene (PTFE) on the Ultra-high molecular weight polyethylene (UHMWPE) mechanical and physical properties. It has been prepared three types of blends (95:5, 90:10 and 85:15) of UHMWPE: PTFE by compression method. Stress-Strain curves of polymer blends have been showed that higher ultimate strength and Young modulus were at 95:5 and decreased gradually as wt. \% PTFE increased. FTIR inspection has been also accomplished. Finally SEM results showed incompatibility between the polymers with presence of boundaries between the binary polymers phases.

Keywords: Polymer blend, UHMWPE, PTFE, Mechanical properties. 
Study the Morphological and Mechanical Properties of Ultra-high Molecular weight polyethylene UHMWPE: Polytetrafluroethylene PTFE binary blends
Alyaa H .Abdalsalam
OlfatA.Mahmood
Gaid K.Salman

\section{دراسة الخواص الميكانيكية و المجهرية للخلائط الثنائية لبولي اثليلين عالي الوزن الجزيئي UHMWPE}

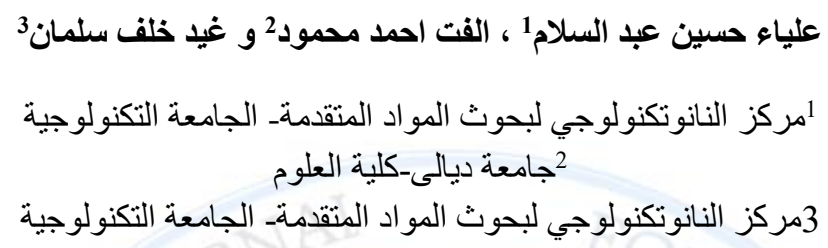

\section{الخلاصة}

في هذا البحث، قد تم البحث في تأثير أضافة بوليمر عالي الكفاءة وهو بولي اثثلين تترا فلورو اثيلين على الخواص الميكانيكية

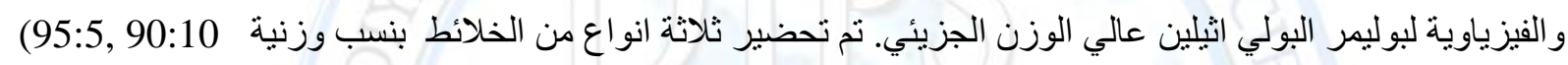

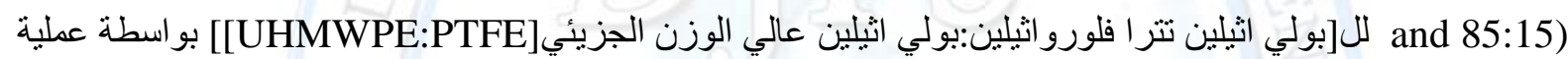
الكبس. ولقد بينت منحنيات الاجهاد_الانفعال للخلائط البوليمرية ان اقصى مقاومة شد ومعامل مرونة كانت عند نسبة وتتناقص تدريجيا بزيادة النسبة الوزنية ل PTFE. فحص تحو لات فورير بواسطة الاشعة الحمر اء(FTIR) تم انجازه ايضا. اخيرا اظهرت صور المجهر الالكتروني الماسح عدم التو افقية بين البوليمرين مع وجود الحدود بين اطوار البوليمر الثنائي.

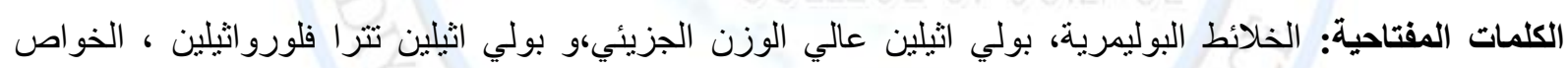
الميكانيكية.

\section{Introduction}

Polytetrafluroethylene (PTFE) presently discover increasing Using in high performance seals due to its remarkable properties like high chemical resistivity, low coefficient of friction and high temperature stability [1,2]. Yanhong Yan et.al prepared advance composite materials based on PTFE reinforced with expanded Graphite fiber and various nano particles of metal such as $\mathrm{Cu}$ and ceramics including $\left(\mathrm{TiO}_{2}, \mathrm{~S} \mathrm{iO}_{2}\right.$ and $\mathrm{Al}_{2} \mathrm{O}_{3}$. Results of Stress-displacement and stress relaxation revealed that ternary composite materials have viscoelastic behavior and seem to be relatively brittle; finally they have been considered that these materials are useful to be used in severe environments [4].JayashreeBijwe et.al investigated the effect of inclusion PTFE in polyether ether ketone (PEEK) polymer. Results showed improvement in PEEK performance [5]. 
Study the Morphological and Mechanical Properties of Ultra-high Molecular weight polyethylene UHMWPE: Polytetrafluroethylene PTFE binary blends
Alyaa H .Abdalsalam
OlfatA.Mahmood
Gaid K.Salman

Ultra-high molecular weight polyethylenediffers from the other Polyethylene types in its average molecular weight which is nearly higher than $10^{6}$, which can be known from measurement of viscosity [6, 7].UHMWPEis a marvelous polymer with excellent physical and mechanical properties such as wear and abrasion resistance, chemical inertness, lubricity, impact toughness [8]. Thein Kyu prepared three types of polymer blends from types of polyethylene; blends of different grades of polyethylene have been prepared (Ultra high molecular weight polyethylene, linear low density polyethylene, low density poly ethylene and high density polyethylene). DSC results of blends showed that compatibility between them in the melting stat which indicates that they form miscibility also UHMWPE with linear low density polyethylene (LLDPE) and high density polyethylene (HDPE) showed some co crystallinity this is interpreted to the long chain branching of conventional LDPE. Results of stress-strain of the above blends show some linearity relationship with composition, except in the last blend UHMWPE-LDPE [9].

A new approach in science and technology developed by blending two different polymers in a way to tailor their both properties in a one single material.The developed characteristics of blends depend strongly on morphology which usually defined by size and shape of distributed particles [10]. With above literature it can be found that most of them tries to improve the performance of polymer matrix using reinforcement materials usually ceramics but in this study the goal was to investigate the effect of high performance polymer addition to another matrix polymerthrough mechanical and morphological inspections.

\section{Materials and Experimental procedure}

Ultra-high mw polyethylene was acquired in powder form JIUJIANG ZHONGKE XINXING NEW MATERIAL CO., LTD China, model No. XH-804 and the mechanical properties of UHMWPE grade were shown in table (1).Polytetraflouroethylene polymers provided from ZIBO BAINAISI CHEMICAL CO., LTD-China some mechanical and physical properties are shown in table (2). 
Study the Morphological and Mechanical Properties of Ultra-high Molecular weight polyethylene UHMWPE: Polytetrafluroethylene PTFE binary blends
Alyaa H .Abdalsalam
OlfatA.Mahmood
Gaid K.Salman

Table (1) shows properties of UHMWPE polymer materials.

\begin{tabular}{|c|c|c|c|c|c|c|c|}
\hline & $\begin{array}{c}\text { Molecular } \\
\text { weight } \\
(\mathbf{m i l} / \mathbf{m o l})\end{array}$ & $\begin{array}{c}\text { Density } \\
\left(\mathbf{g m} / \mathbf{c m}^{\mathbf{3}}\right)\end{array}$ & $\begin{array}{c}\text { Grain } \\
\text { size } \\
\mathbf{4 0}\end{array}$ & $\begin{array}{c}\text { Granularity } \\
>\mathbf{3 0} \\
\text { mesh }\end{array}$ & $\begin{array}{c}\text { Tensile } \\
\text { elongation } \\
\text { at break } \\
\text { \% }\end{array}$ & $\begin{array}{c}\text { Tensile } \\
\text { strength } \\
(\mathbf{M P a})\end{array}$ & $\begin{array}{c}\text { Impact } \\
\text { strength } \\
\text { Izod } \\
\left(\mathbf{K J} / \mathbf{m}^{2}\right)\end{array}$ \\
\hline $\begin{array}{c}\text { UHMWPE } \\
(\mathbf{X H - 8 0 4})\end{array}$ & $\begin{array}{c}424 * 10^{\wedge} 5 \\
\pm 20\end{array}$ & $0.93-0.95$ & 95 & $99.6 \%$ & 250 & 30 & 70 \\
\hline
\end{tabular}

Table (2) shows properties of PTFE polymer materials.

\begin{tabular}{|c|c|c|c|c|c|c|}
\hline & $\begin{array}{c}\text { Tensile Strength } \\
(\mathrm{Mpa})\end{array}$ & $\begin{array}{c}\text { Elongation at } \\
\text { Rupture (\%) }\end{array}$ & $\begin{array}{c}\text { Volume } \\
\text { Density }(\mathrm{g} / \mathrm{l})\end{array}$ & $\begin{array}{c}\text { Moisture } \\
\text { Content, }(\%) \leq\end{array}$ & $\begin{array}{c}\text { Relative } \\
\text { Density }\end{array}$ & $\begin{array}{c}\text { Particle Size } \\
(\mu \mathrm{m})\end{array}$ \\
\hline PTFE & 28.5 & 300 & 400 & 0.021 & 2.144 & 16 \\
\hline
\end{tabular}

\section{Blending and compression}

Polymer blends have been prepared by mixing the two polymers in Nano ball mill for 15 minutes to have homogeneous mixture then placed in a stainless steel mold $(150 * 50 * 4) \mathrm{mm}$ preparing for hot pressing at $190{ }^{\circ} \mathrm{C}$ for 45 minutes and pressure $10 \mathrm{MPa}$ for ten minutes to have blocks of polymer blends.

\section{Mechanical test}

Samples were prepared for the tensile test in accordance with ASTM D638-87[14]. A computerized universal testing machine model (WDW-200D Jinan Shijin Group companychina) was used to conduct a test at a constant cross head speed of the order $5 \mathrm{~mm} / \mathrm{min}$ at room temperature. Tensile load wasapplied till the failure of the sample and stress -strain curve was obtained.

The modulus of elasticity was evaluated using the following equation:

$E=\frac{\sigma_{y}}{L-L_{o} / L_{o}} \ldots \ldots$ 
Study the Morphological and Mechanical Properties of Ultra-high Molecular weight polyethylene UHMWPE: Polytetrafluroethylene PTFE binary blends
Alyaa H .Abdalsalam
OlfatA.Mahmood
Gaid K.Salman

Where $\sigma_{y}$ is the stress at yield, $\mathrm{L}$ is the length of sample at yield and Lo is the initial length.

Scanning Electron Microscope (SEM), model (Tescan VEGA-SB) made in Belgium available in Nanotechnology and Advanced Materials Research Center/ University of Technology is used to examine the morphology of polymer blends.

Finally, FTIR test is performed according to (ASTM E1252) by using Fourier transform infrared spectrometer instrument (available in Material Engineering Department model (TENSOR 27) made in Germany, by (Bruker Optics Company).

\section{$\underline{\text { Results and Discussion }}$}

\section{FTIR results}

IR- spectra of Ultra-High Molecular Weight PE shows the main five peaks (2912.87, 2843.92, 1470.46, 729 and $718 \mathrm{~cm}-1$ ) as shown in fig (1) which indicates to Asymmetric stretching of the $-\mathrm{CH}_{2}$, symmetric stretching of the $-\mathrm{CH}_{2}$ aliphatic groups , $\mathrm{C}-\mathrm{H}$ bending deformation, $=\mathrm{CH}_{2}$ out-of-plane bending and $\mathrm{C}-\mathrm{H}$ rocking deformation respectively as shown in table (3)[11].

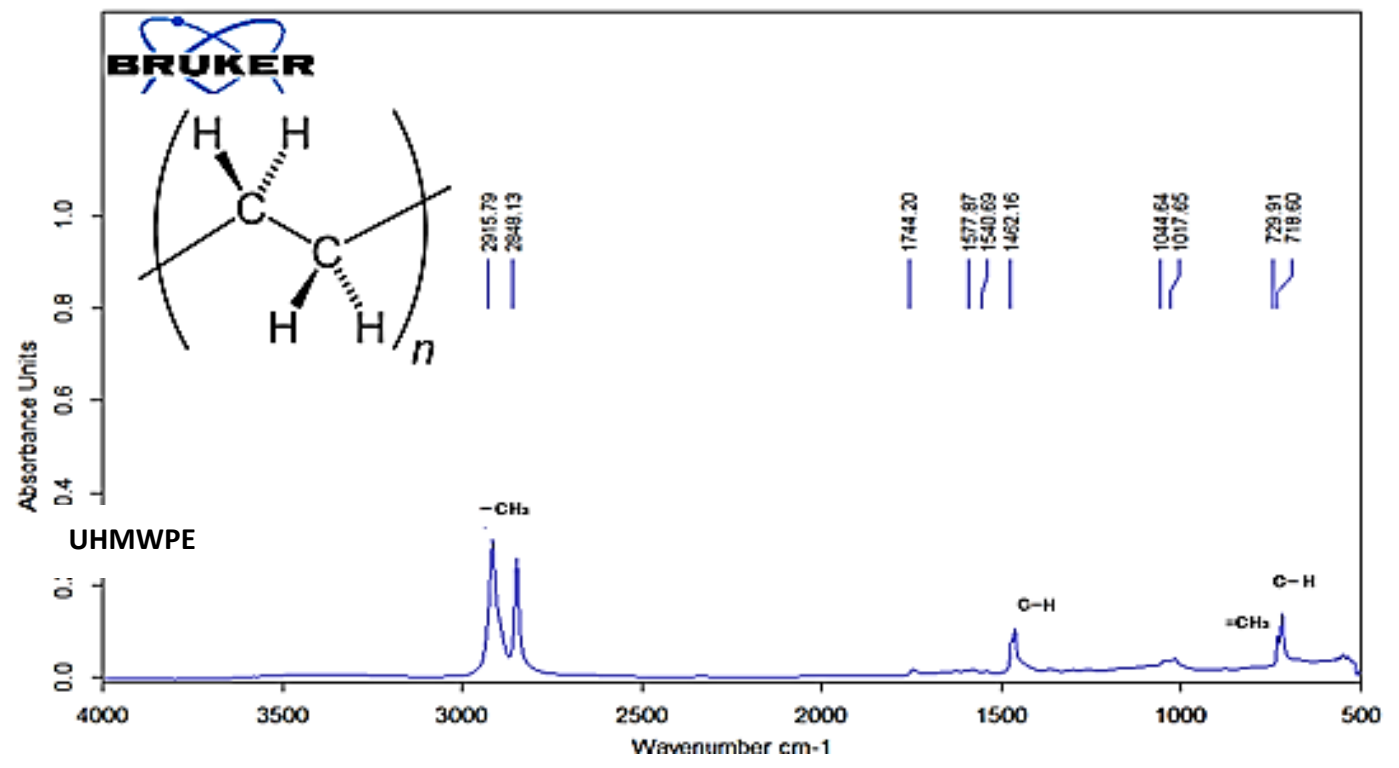

Figure (2) shows FTIR results of UHMWPE. 
Study the Morphological and Mechanical Properties of Ultra-high Molecular weight polyethylene UHMWPE: Polytetrafluroethylene PTFE binary blends
Alyaa H .Abdalsalam
OlfatA.Mahmood
Gaid K.Salman

As for polytetrafluoroethylene which contains four flour atoms and its basic assignments which based on the formula of PTFE: $-\left[-\mathrm{CF}_{2}-\mathrm{CF}_{2}-\right] n-$ are $1251,1155,705,632,511 \mathrm{~cm}^{-}$ ${ }^{1}$ belong to the different modes of $\mathrm{CF}_{2}$ groups as shown in fig (2) and table (3)[12,13]. More over the blend FTIR shown in fig (3) showed that there was no new bonds have been appeared and most UHMWPE absorption peaks have been appeared and without shifting, Still some peaks of PTFE have been appeared in the blend [UHMWPE: 15PTFE] with small shifting which may belong to the high percentage of PTFE as compared with the other blends as shown in table (3).

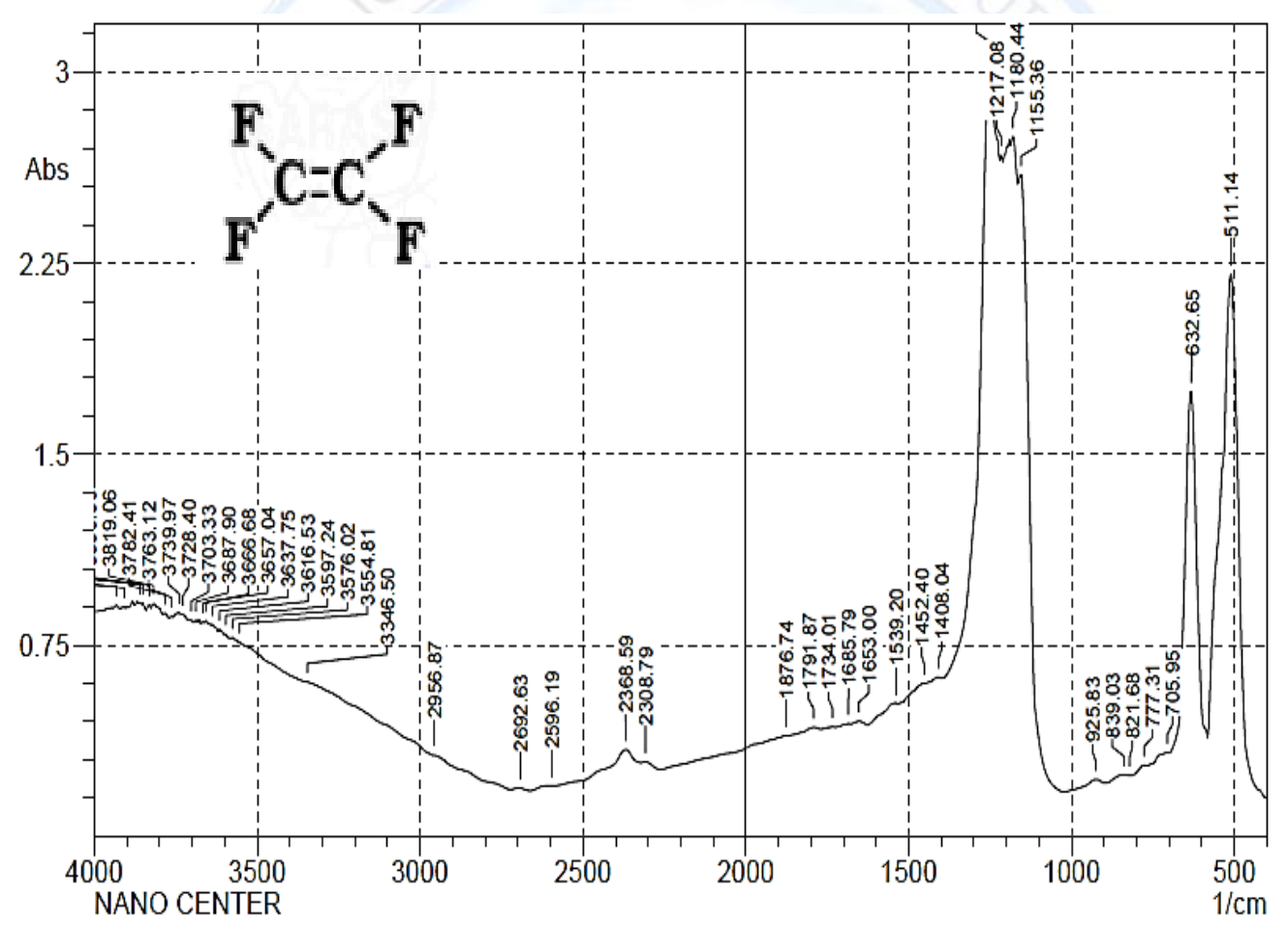

Figure (2) shows FTIR results of PTFE. 
Study the Morphological and Mechanical Properties of Ultra-high Molecular weight polyethylene UHMWPE: Polytetrafluroethylene PTFE binary blends
Alyaa H .Abdalsalam
OlfatA.Mahmood
Gaid K.Salman

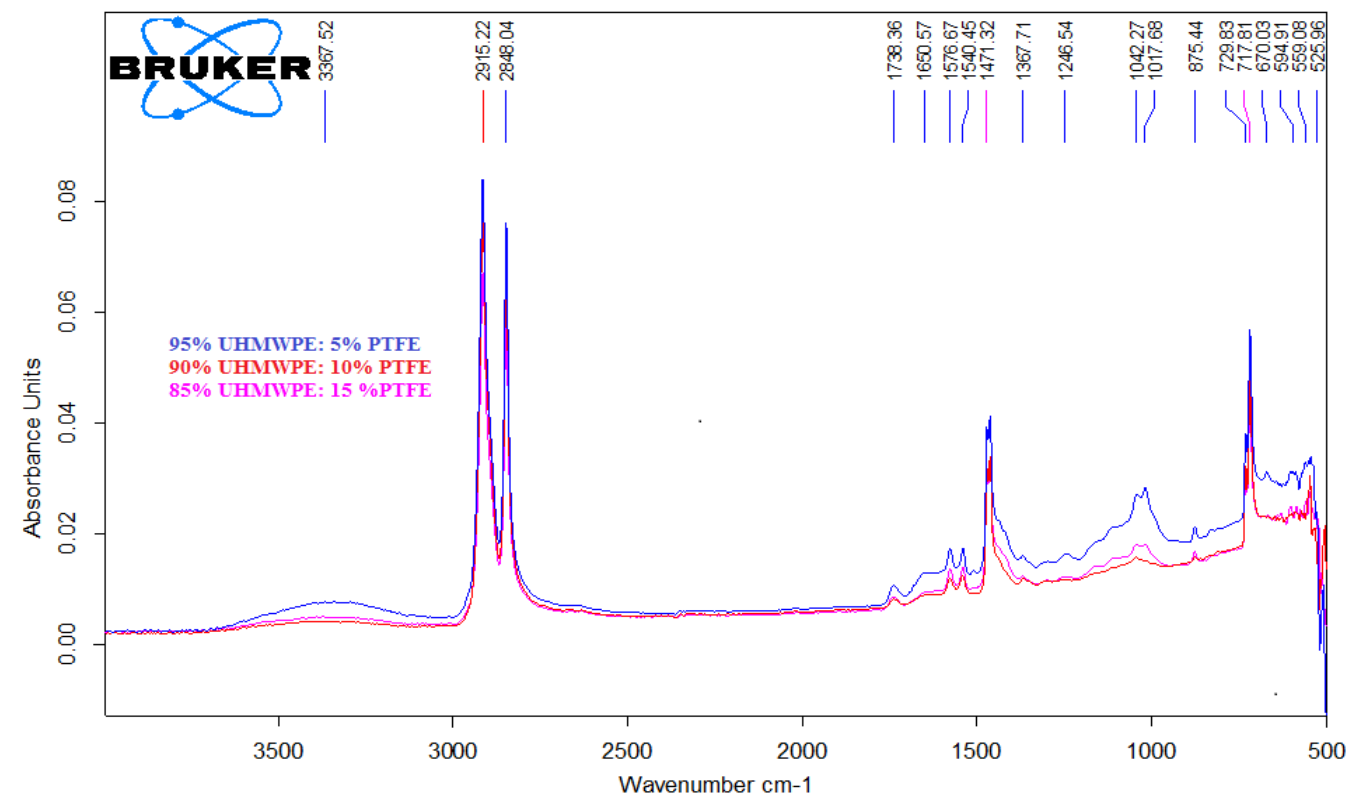

Figure (3) shows FTIR of (UHMWPE and PTFE) polymer blends.

Table (3) shows IR- spectrum of UHMWPE,PTFE and their blends.

\begin{tabular}{|c|c|c|c|c|c|}
\hline Association & UHMWPE & PTFE & $\begin{array}{c}\text { UHMWPE } \\
\text { 5\% PTFE }\end{array}$ & $\begin{array}{c}\text { UHMWPE } \\
\text { :10\%PTFE }\end{array}$ & $\begin{array}{c}\text { UHMWPE: } \\
\text { 15\%PTFE }\end{array}$ \\
\hline $\begin{array}{c}\mathrm{CF}_{2} \text { asymmetric } \\
\text { stretching }\end{array}$ & - & 1251 & - & - & - \\
\hline $\begin{array}{c}\mathrm{CF}_{2} \text { symmetric } \\
\text { stretching }\end{array}$ & - & 1155.36 & - & - & 1152.91 \\
\hline $\mathrm{CF}_{2}$ scissoring & - & 705.95 & - & - & - \\
\hline $\mathrm{CF}$ deformation & - & 632.65 & - & - & 638.55 \\
\hline $\begin{array}{c}\mathrm{CF}_{2} \text { bending } \\
\text { stretching of -CH }\end{array}$ & - & 511.36 & 543.64 & 545.70 & 545.86 \\
\hline $\begin{array}{c}\text { symmetric stretching } \\
\text { of -CH }\end{array}$ & 2843.92 & - & 2848.04 & 2847.93 & 2847.88 \\
\hline $\begin{array}{c}\mathrm{C}-\mathrm{H} \text { bending } \\
\text { deformation }\end{array}$ & 1470.46 & - & 1462.35 & 1471.33 & 1471.32 \\
\hline $\begin{array}{c}\text { (CH } \mathrm{CH}_{2} \text { out-of-plane } \\
\text { bending }\end{array}$ & 729 & - & 729.83 & 730.03 & 729.88 \\
\hline $\begin{array}{c}\mathrm{C}-\mathrm{H} \text { rocking } \\
\text { deformation }\end{array}$ & 718 & - & 717.54 & 717.49 & 717.81 \\
\hline
\end{tabular}




\section{DIYALA JOURNAL FOR PURE SCIENCES}

Study the Morphological and Mechanical Properties of Ultra-high Molecular weight polyethylene UHMWPE: Polytetrafluroethylene PTFE binary blends
Alyaa H .Abdalsalam
OlfatA.Mahmood
Gaid K.Salman

\section{SEM results}

Scanning electron microscope photographs of UHMWPE: PTFE polymer blend are shown in fig ( $4 \mathrm{a}, \mathrm{b}$ and $\mathrm{c}$ ). Results interpreted the reasons of the in improvement in mechanical properties, which is the incompatibility that led tothe segregation that shown below which corresponding with MohdAmran research [14] in the immiscibility between PP and PTFE. Also it may be seen that PTFE flakes imbedded in UHMWPE matrix and tries to expand to be mixed and united with the other polymer phase without melting since the difference in melting point between the two polymers, still the need for copolymers is necessary to enhance the compatibility and strengthening the boundaries between them. Moreover, it should be noted that some PTFE particles are deformed into a fibrous shape owing to the applied squeeze flowas well as the localized shear deformation and this can be seen in photograph (4.c) below.

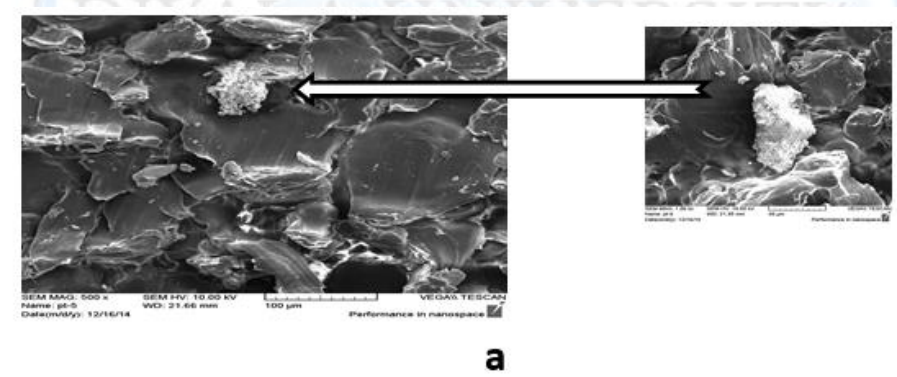

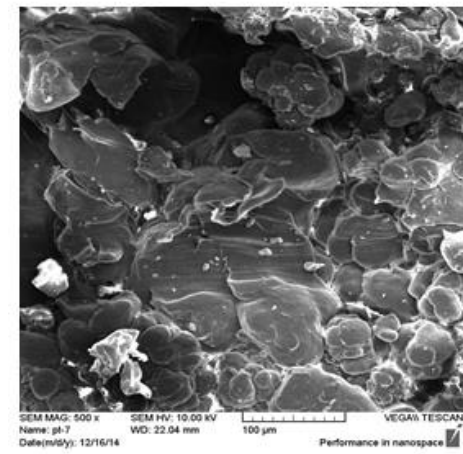

b

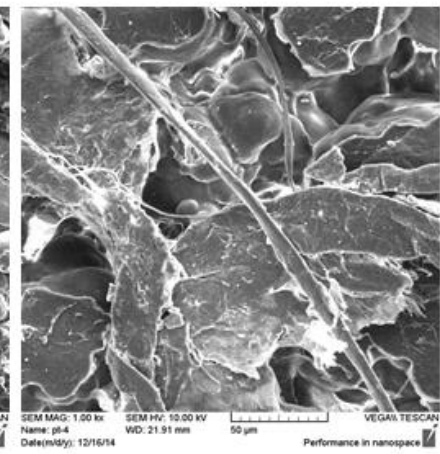

C

Figure (4a,b and c) shows SEM images ofpolymer blends. 
Study the Morphological and Mechanical Properties of Ultra-high Molecular weight polyethylene UHMWPE: Polytetrafluroethylene PTFE binary blends
Alyaa H .Abdalsalam
OlfatA.Mahmood
Gaid K.Salman

\section{Tensile results}

It has been noticed the change in the behavior of the neat polymer (i.e. Ultra high molecular weight polyethylene) as polytetrafluoroethyleneadded as shown in fig (5). Results showed how UHMWPE converted from soft and tough into hard and brittle but still tensile strength of the pure polymer higher than all ratio of UHMWPE: PTFE polymer blends as shown in fig (6), this may attributed to the weak compatibility between UHMWPE and PTFE which may lead us to think about copolymers that strengthen the interfacial areas. The same can be seen in Young modulusproperty (i.e. values of E blends less than the UHMWPE) further more they decreases as wt. \% PTFE increased as shown in fig (7) and the reason also will be the same .Table (4) shows ultimate strength and young modulus values of the blends.

Table (4) shows the mechanical properties of polymer blends.

\begin{tabular}{|c|c|c|}
\hline & $\begin{array}{c}\text { Ultimate tensile } \\
\text { strength } \\
\text { (MPa) }\end{array}$ & $\begin{array}{c}\text { Young modulus } \\
\text { (MPa) }\end{array}$ \\
\hline UHMWPE & 22.8 & 618 \\
\hline UHMWPE:5PTFE & 19 & 400 \\
\hline UHMWPE:10PTFE & 15 & 300 \\
\hline UHMWPE:15PTFE & 12 & 208 \\
\hline
\end{tabular}


Study the Morphological and Mechanical Properties of Ultra-high Molecular weight polyethylene UHMWPE: Polytetrafluroethylene PTFE binary blends
Alyaa H .Abdalsalam
OlfatA.Mahmood
Gaid K.Salman

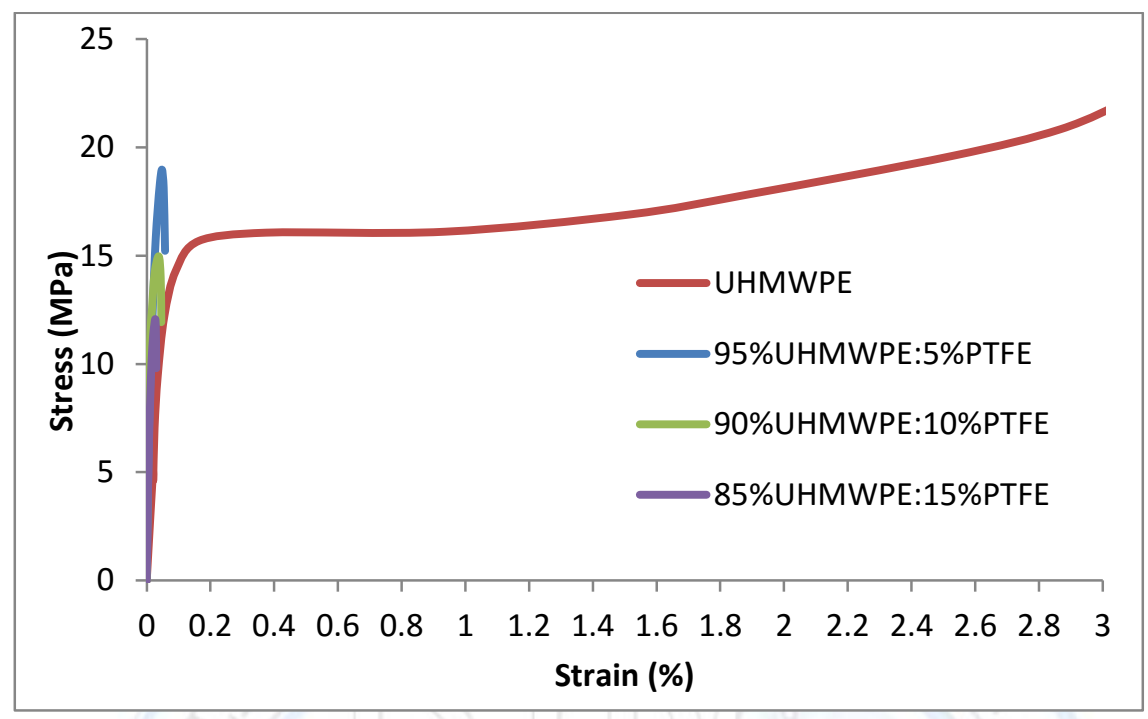

Figure (5) shows stress-strain behavior of UHMEPE-PTFE polymer blends.

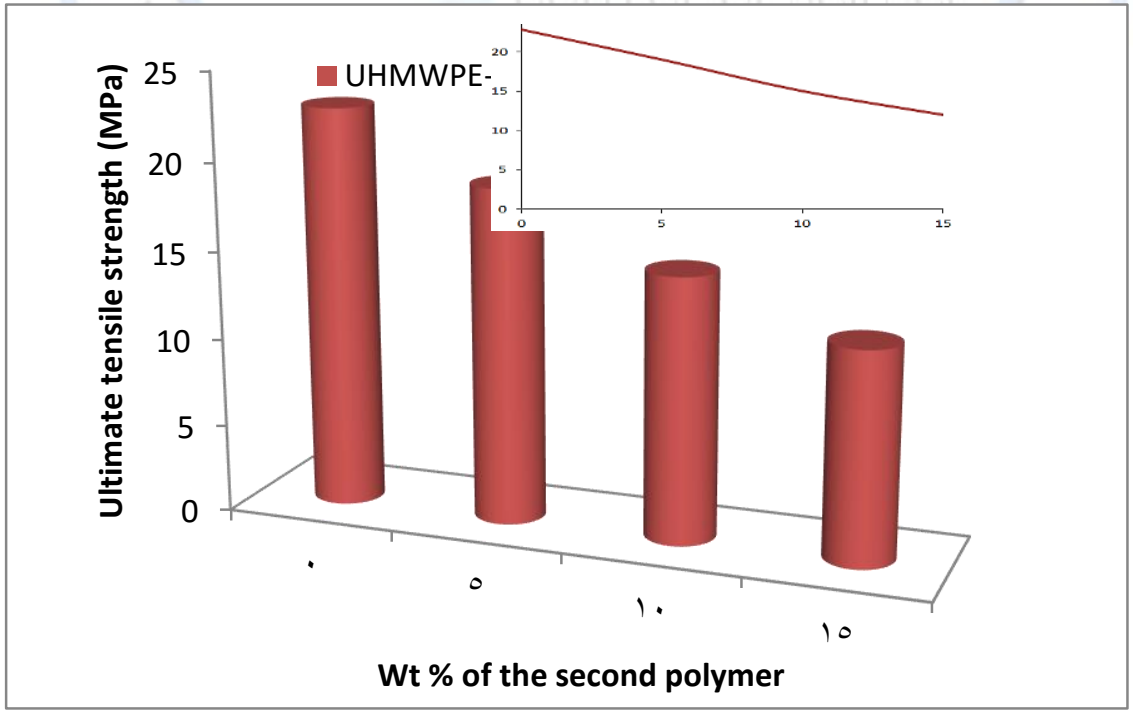

Figure (6) shows Ultimate tensile strength property UHMWPE-PTFE blends. 
Study the Morphological and Mechanical Properties of Ultra-high Molecular weight polyethylene UHMWPE: Polytetrafluroethylene PTFE binary blends
Alyaa H .Abdalsalam
OlfatA.Mahmood
Gaid K.Salman

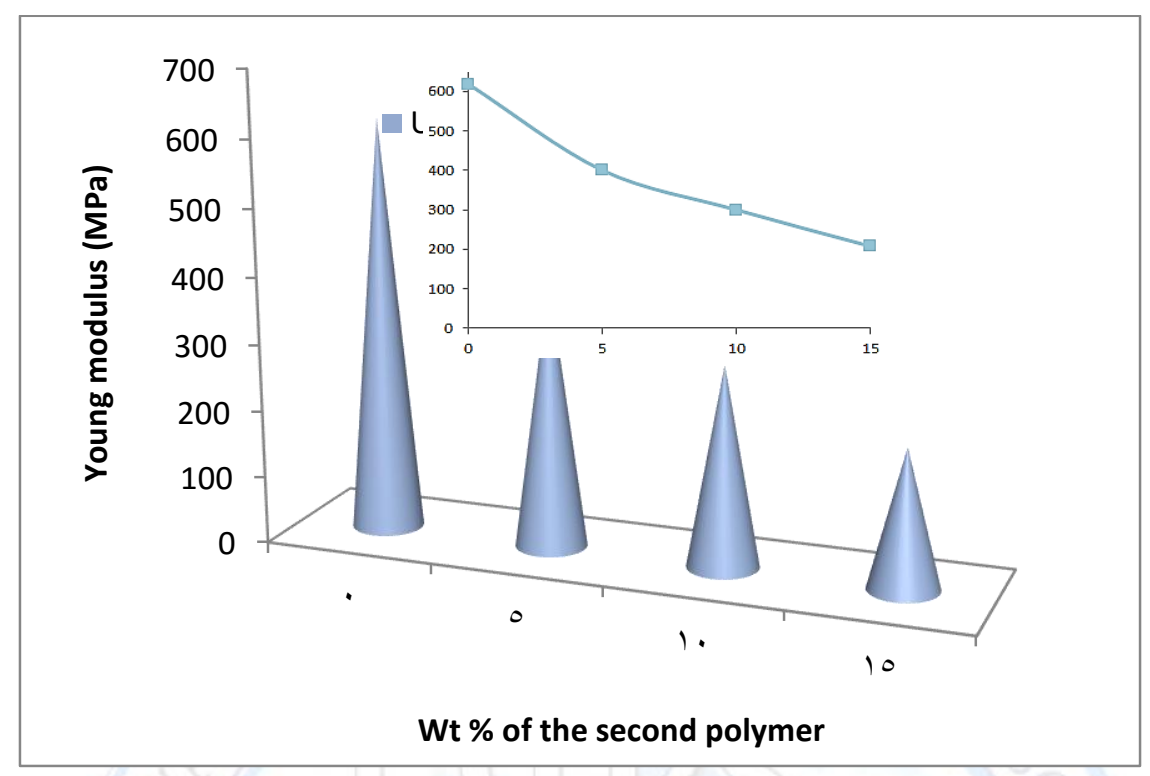

Figure (7) shows Young modulus values of UHMWPE-PTFE blends.

\section{Conclusion}

It has been concluded that the effect of PTFE was not so good in improvement the mechanical properties including ultimate strength and Young modulus since there were decrement in both of them which can be interpreted to the incompatibility between the two polymers leading to immiscibility phenomena, which has been proved by SEM.

Still the change in the behavior of UHMWPE from soft and ductile into stiff and brittle is pronounced due to the difference structure of PTFE polymer as compared with simple structure of PE. Moreover FTIR results showed appearance of both polymers peaks with no shifting. 
Study the Morphological and Mechanical Properties of Ultra-high Molecular weight polyethylene UHMWPE: Polytetrafluroethylene PTFE binary blends

\section{$\underline{\text { References }}$}

1. R. Navarro, S. Ferradiz, J. Lopez and V.J.Segu,"The influence of polyethylene in the mechanical recycling of PET", J.Mater.Process.Technol.195 (2008), pp.110-116.

2. U. Sundararaj, "Micro- and nanostructured multiphase polymer blend systems: phase morphology and interfaces", CRC Press, Taylor \& Francis, USA, 2006.

3. P.J. Rae, D.M. Dattelbaum,'The properties of poly(tetrafluoroethylene) (PTFE) in compression”, science direct ,Polymer 45 (2004),pp. 7615-7625.

4. Yanhong Yan, ZhiningJia, Yulin Yang, "Preparation and Mechanical Properties of PTFE/Nano-EGComposites Reinforced with Nanoparticles” Procedia Environmental Sciences 10 ( 2011),pp. $929-935$.

5. JayashreeBijwe, Sukanta Sen, Anup Ghosh,'Influence of PTFE content in PEEKPTFE blends on mechanicalproperties and tribo-performance in various wear modes", Science direct, Wear 258 (2005),pp.1536-1542

6. F. Ronkay, L. M'esz'aros, G. J'anoki, and T. Czvikovszky, "The effect of pre-electron beam irradiation of HDPE on the thermal and mechanical properties of HDPE/PET blends", Mater. Sci. Forum 659(2010), pp.85-90

7. Julia S. Petronyuk, Olga V. Priadilova, Vadim M. Levin, Olga A. Ledneva, Anatolii A Popov ,"Structure and elastic properties of immiscible LDPE-PP blends: dependence on composition", Mat. Res. Soc. Synup. Proc. Vol. 740 (2003), pp.261-266.

8. Steven M. Kurtz,"UHMWPE Biomaterials Handbook, Ultra High Molecular Weight Polyethylene in Total Joint Replacement and Medical Devices(Second Edition)",Science direct,2009.

9. Thein Kyu and ParimalVadhar,"Cocrystallization and miscibility studies of blends of ultrahigh molecular weight polyethylene with conventional polyethylenes", Journal of Applied Polymer Science ,vol. 32(6):pp.5575 - 5584.

10. Sionkowska A. Current research on the blends of natural and synthetic polymers as new biomaterials: Review. Prog.Polym.Sci. 2011; 36: pp.1254-1276.

11. G. E. Selyutin1, Yu. Gavrilov1, e. N. Voskresenskaya1, V. A. Zakharov, v. E. Nikitin2 and v. A. Poluboyarov," Composite Materials Based on Ultra High Molecular 
Study the Morphological and Mechanical Properties of Ultra-high Molecular weight polyethylene UHMWPE: Polytetrafluroethylene PTFE binary blends
Alyaa H .Abdalsalam
OlfatA.Mahmood
Gaid K.Salman

Polyethylene: Properties, Application Prospects", Chemistry for Sustainable Development (2010),Vol. 18 ,pp. (301-314).

12. Judith Mihály, Silvana Sterkel, Hugo M. Ortner, LászlóKocsis, LászlóHajba, ÉvaFurdyga and János Mink," FTIR and FT-Raman Spectroscopic Study on Polymer Based High Pressure Digestion Vessels", CROATICA CHEMICA ACTA, CCACAA 79 (3) ,pp.497-501,2006.

13. lara T. H. Tran, Alexey Kondyurin, Stacey L. Hirsh, David R. McKenzie and Marcela M. M. Bilek,"Ion-implanted polytetrafluoroethylene enhances Saccharomyces cerevisiae biofilm formation for improved immobilization”, J. R. Soc. Interface (2012) 9, pp.2923-2935.

14. MohdAmran Bin Md Ali, Shogo Nobukawa, and Masayuki Yamaguchi,"Morphology development of polytetrafluoroethylene in a polypropylene melt", Pure Appl. Chem., Vol. 83, No. 10, pp. 1819-1830, 2011. 